\title{
Burying the Beloved: Marriage, Realism, and Reform in Modern Iran
}

\section{Citation}

Najmabadi, Afsaneh. 2015. "Burying the Beloved: Marriage, Realism, and Reform in Modern Iran." Iranian Studies 48 (2) (February 24, 2014): 294-297. doi:10.1080/00210862.2014.1001179.

\section{Published Version}

10.1080/00210862.2014.1001179

\section{Permanent link}

http://nrs.harvard.edu/urn-3:HUL.InstRepos:14117788

\section{Terms of Use}

This article was downloaded from Harvard University's DASH repository, and is made available under the terms and conditions applicable to Open Access Policy Articles, as set forth at http:// nrs.harvard.edu/urn-3:HUL.InstRepos:dash.current.terms-of-use\#OAP

\section{Share Your Story}

The Harvard community has made this article openly available.

Please share how this access benefits you. Submit a story.

Accessibility 
Amy Motlagh, Bury the Beloved: Marriage, Realism, and Reform in Modern Iran. Stanford: Stanford University Press, 2012.

Amy Motlagh's book is a welcome contribution to the field of Iranian literary-historical and gender studies. It is deeply interdisciplinary, thoroughly grounded in archival research; it is theoretically informed, and analytically strong. The book sustains a critical engagement with existing scholarship and builds upon it in novel directions. Its approach and propositions open up the possibility of entering into productive intellectual conversations, beyond Iranian studies, with histories of modernity, comparative literary studies, women and gender histories.

The book opens with a powerful introduction in which Motlagh clearly lays out the central themes and analytical moves she will follow. Starting with the seemingly privileged place of death and burial in the writings of many Iranian modernists, she asks: "What to make of these troubled movements of Iranian bodies across time and space? [She is here referencing Tahirah Qurrat al-'Ayn's strangling and disposal of her body into a garden well, Hidayat's suicide and burial near Paris, and both Pahlavi shahs' death in exile and (initial) burial abroad.] And what relationship do these material bodies bear to the restive corpse of the beloved in Hedayat's masterpiece, which is revivified, dismembered, and persistently sentient in portions in part I - only to be rearticulated as the narrator's wife in part II, then killed again?" (p. 3) She pursues this question further by bringing out other figures of death and burial from Iranian modern masterpieces, including the body of Yusuf, "the hero-martyr of Simin Daneshvar's Savushun," and the haunting of Sitarah's ghost in Parsipur's Tuba and the Meaning of Night.

Motlagh relates this observation to one of the central arguments of the book: that disowning and mourning the past, and burying particularly troublesome figures associated with that past, are critical elements of enabling the project of modernity and articulation of its auto-narrative. The particularly troublesome figure she focuses on is the beloved from Iranian literary-cultural tradition: "Overdetermined, the beloved evokes many ideas at once: the refuge of the garden; physical passion; a sacred ideal. The celebration of marriage and the ideal of the companionate wife in legal discourse and in fiction depended on the burial of this ambiguity in and of the past." (p. 3) The beloved of modern fiction, Motlagh notes, is decidedly feminine.

But how could this deeply ambiguous figure be translated into the modern wife? It is here that Motlagh makes one of her most novel moves. In her historical approach, Motlagh combines her analysis of the "murderous" effects of this disambiguation in the fiction of prominent modernist writers with state codification of civil law in twentieth-century reforms of marriage and family laws. While scholarship on Iranian modernity has analyzed modern fiction as a powerful domain for re-articulation of gender relations, and legal and anthropological writings have critically engaged with modern family code and legal reforms of the Pahlavi period, Motlagh's book is the first I know of that brings these two distinct threads of cultural transformation (along with their two bodies of scholarship) into a combined symbiotic synopsis. Beyond the suturing of these two discourses, she also notes that many literary figures were at once political commentators, 
and as public intellectuals and newspaper columnists, they advocated the kind of legal reforms that would re-envisage family as a modern heterosexual unit centered on the conjugal couple.

Bringing these two usually held-apart modes of narrative modernization (literary and legal) produces unexpected insights. Motlagh argues persuasively that the political-legal discourse about reform of marriage laws and women's rights, in two important periods -the late1920s through mid-1930s, and then again in the 1960s - can be productively read with the fiction of the same periods: both are formed around a set of notions that set the emerging and shifting outlines of new manhood and womanhood. She focuses on marriage as a central metaphor through which both legal and literary texts read gender in twentieth-century Iran. Through sensitive close reading, Motlagh demonstrates how these texts informed each other's meaning, reception, and reading possibilities. As she notes, while many historians have noted that many late-nineteenth-/early twentieth-century intellectuals penned both fiction and political essays arguing for reforms, they have not read these writings in terms of how writing in each genre shaped the other and how this creative symbiosis continued in the later state-sponsored reforms and their intellectual advocates, not only in newspaper article but in short stories and later novels as well. She analyzes how both genres had a persistently prescriptive dynamic (an argument that had also been advanced by Camron Amin's 1996 doctoral dissertation but has remained underutilized) and shows how by breaking away from reading them as "mirror of social reality" - a common narrative strategy among many scholars of modern Iran - one can produce original insights into cultural transformations and legal changes of the period. Motlagh carries this argument through specific analysis of several key novels of each period in conjunction with corresponding changes in the legal discourse. As she engages with these texts, she brings out previously neglected issues (for example: the significance of dismemberment in Hidayat's Buf-i kur), comes to new analytical conclusions (for example: how Buf-i kur "demonstrates the difficulty with which a heterosexual aesthetic was transposed onto the poetics of Persian literary practice"), and offers powerful approaches (for example: reading the ambivalences and challenges of public heterosociality and presumptive heterosexuality as crafted in the novels as a way of accessing the reception of legal reforms).

This is a densely argued, yet clearly written, book. Chapter 1 reads Hidayat's The Blind Owl and Buzurg 'Alavi's Chishmhayash [disambiguated into English as Her Eyes] along with and through the 1931 marriage law and the 1936 unveiling act. Chapters 2 and 3 bring the analysis to the 1960s, with particular focus on the writings of women fiction writers (such as Danishvar) as well as women's rights advocates (such as Sadiqah Dawlatabadi, Zahra Khanlari, and Badr al-Muluk Bamdad) who engaged as well in penning didactic fiction writing. This focus on women writers continues in the subsequent chapters (4 and 5) that bring the book into post-1979 decades and writers. Throughout, Motlagh engages both with the content of such writings as well as with the logic of their preferred mode, whether of realism or in the most recent decades the turn to magic realism. 
There are a number of (inevitable?!) typographic errors (p. 46, the year of Reza Shah's abdication should have been 1941 not 1943, and "the Mossadeq coup of 1953" would perhaps be clearer as the coup against Mossadeq), at times analytical lapses that perhaps confirm the power and romanticization of modernist discourse on marriage, such as the prevalent collapse of arranged/obligated marriages as if always forced (p. 53), and unsupported claims (for example, that what followed the 1979 overthrow of the monarchy "was not [what] the majority of the revolution's supporters had envisioned," $p$. 95 - which decades are we talking about and how do we know this?).

Beyond such minor points (a reviewer is obligated to note something!), in its overarching analysis of Iranian modernity, Motlagh's book demands of us to rethink both literary and legal studies of modern Iran and to re-read familiar texts with an eye for what we have missed. 